\title{
$5 \quad$ Mein Wissens-ABC zum Thema Jahresabschlussanalyse
}

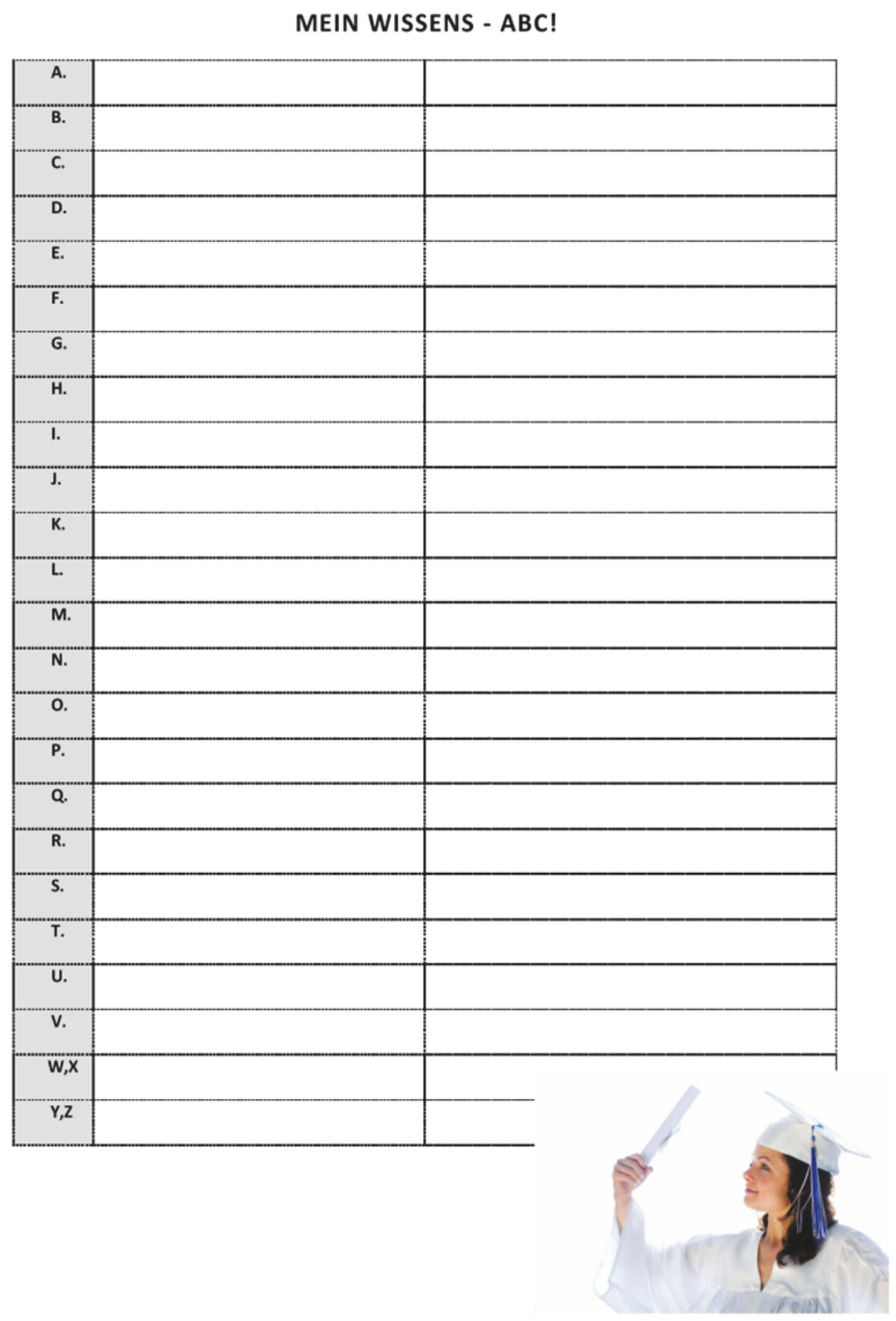

